\title{
Rasch Analysis, Dimensionality, and Scoring of Aggressive Behavior Inventory for Junior High-School Students
}

\author{
Afdal Afdal ${ }^{*}$, Miftahul Fikri², Yudha Ayahputra ${ }^{3}$, Neviyarni $S^{4}$ \\ ${ }^{124}$ Guidance \& Counseling Department, Faculty of Education, Universitas Negeri Padang, 25132, Padang, Indonesia \\ ${ }^{3}$ Guidance \& Counseling Department, Faculty of Education, Universitas Indraprasta PGRI Jakarta, Indonesia
}

\begin{abstract}
Aggressive behavior often appears in junior high-school students who are entering adolescent development and requires serious attention from many parties. To measure these behavioral tendencies, many assessment instruments have been developed but none of them use Item Response Theory. This study aims to develop and test the validity of the instrument of aggressive behavior of junior high-school students, see the level of suitability of the item and see the level of difficulty of the item and be able to see variable maps of the ability of the person to answer and the ability of items to reveal aggressive behavior. This study used a sample of 360 students with 47 items. The analysis technique used is Rasch analysis to test the reliability, person validity, item validity, and rating validity. The analysis showed that overall the inventory developed is valid and reliable (person reliability is 0.89 and item reliability is 0.98.) The rating scale results using the Andrich Threshold Value indicate that the five choices given are valid for respondents. It can be concluded that the inventory behavior aggressive is valid internally to assess aggressive behavior of junior high-school students and can be used by teachers, school counselors in identifying aggressive behavior.
\end{abstract}

Keywords

Rasch model; dimensionality; Aggressive behavior; Students

Article Received: 20 September 2020, Revised: 30 November 2020, Accepted: 18 December 2020

\section{Introduction}

The rapid development of science and technology makes teenagers often experience many challenges in achieving their developmental tasks, especially in the social environment. Teenagers who have failed in developing their sense of identity, will lose direction and have a negative impact on their development and often cause problems and behave negatively [1], [2] one of them is a tendency to behave aggressively[3]-[6].

Aggressive behavior is any form of action to hurt or hurt others, both physically, such as damaging or hurting other people[7], [8]or mentally hurt[9]-[11]. Aggressive behavior shows a negative effect on the effectiveness of learning and needs serious treatment by the counselor so that this behavior does not develop in a worse direction, especially in the achievement of developmental tasks[12]. The results found $69 \%$ of teenage respondents had had a fight, which was dominated by male teenage students[13]. While other studies show that $56.66 \%$ of respondents have participated in brawls[14].

Various studies regarding aggressive behavior show many things that cause individuals to behave aggressively, namely excessive alcohol consumption[15]-[17], excessive stress [15], [18], parenting style is wrong[19]-[22], frustration is too high[15], [21],provocation from others[11], [15], [21],can't manage themselves[11], [21], [23], [24]maladaptive emotion regulation[25]-[27], environment that is not conducive[10], [15], [19], [21], [28], [29] and the result of imitating violent video games[30]-[32].Aggressive behavior is often carried out by individuals and groups in the form of brawls, insults, beatings, family violence, and emotional violence that causes violence and criminal acts[8], [9], [33][35].

Education has an important role in building human ecological beliefs, understanding and behavior. The emergence of various natural damages, disasters, floods, landslides and other environmental crises is assessed due to human activities outside proportional limits, religious and cultural values [36]. So that education services in schools can be optimal[37], there needs to be identification of students' aggressive behavior.

The problem is that until now there is no instrument that can be used to measure the aggressive behavior of junior high school students who are tested using the item response theory. The development of this instrument uses various concepts of aggressiveness, including verbal aggression[38]direct and indirect aggression[39],proactive aggression with reactive[40], or instrumental aggression 
with impulsivity. In addition, there are various instruments of aggressive behavior[41][43]which is used as an initial guideline. One widely accepted instrument is the Buss-Perry Aggressive Questionnaire (BPAQ) developed by AH Buss \& Perry, (1992) which is often referred to as one of the most popular aggressiveness questionnaires since it was published by several researchers[44], [45].

Furthermore, Buss and Durkee revised BPAQ to Buss-Durkee Hostility Inventory (BDHI) into 7 factors and some items were repaired or eliminated, and 5-point Likert type scale items replaced the right-wrong responses in the answer choices (AH) Buss \& Perry, (1992). BPAQ has been used in various countries by adjusting to the language in that country, namely: Portuguese [43]China[46], French[47], Italy [48] and Germany [41]. However, the measurement of Aggressive Questionnaire (AQ) has not been done in Indonesian culture, especially by cultures that adhere to the matrilineal kinship system. The Minangkabau community is known as one of the largest ethnic groups in the world that adheres to the matrilineal kinship system[49]. The characteristics of the matrilineal kinship system are the offspring calculated according to the maternal line, the tribe formed according to the maternal line, exogamous marriage, revenge, and inheritance rights inherited from mother to daughter [50]. Hanani, (2016) explains that ideally there is no violence in Minangkabau. This is proven by the philosophy adopted by the Minangkabau culture, namely the philosophy of "Kato Nan Ampek"[52], [53]. This philosophy means that the politeness of the Minang community in communicating and speaking is important in patterns of communication between individuals, which can certainly eliminate aggressive behavior. However, aggressive behavior is still displayed in the Minangkabau community with various cases of problems of domestic violence[54].

The uniqueness of this condition requires the identification of aggressive behavior through an aggressive questionnaire using the basic BPAQ theory (AH Buss \& Perry, 1992) that has been adapted to the Minangkabau language and culture, so that this instrument can later help teachers in the field of study and counselors as educational practices [55]to intervene in students who have aggressive behavior with appropriate services.

\section{Materials and Methods}

This research uses the type of Research and
Development (R \& D) research by using a 4-D development model (Define, Design, Development and Research) which refers to the development steps raised by Trianto (2012).

The research sample consisted of 360 studentsin 8 junior high schools (public and private) West Sumatra. The research data were analyzed using the Rasch model using statistical analysis of suitability[57][59].Statistical analysis of suitability using MNSQ outfit parameters with ideal range $(+0.5$ to +1.5$),$ ZSTD outfit with ideal range $(-2.0$ to $+2.0)$ to find the suitability of items and people, detect measurement biases, item strengths and weaknesses, and the level of difficulty of the items from the ability of the person to answer and the ability of items to reveal aggressive behavior [57].

The instrument development steps use the Oriondo and Antonio Models, namely: (1) planning instrumentsconsisting ofdetermination of instrument objectives, Determination of instrument objectives, determination of competencies tested, determination of the material being tested, grid arrangement, writing items based on the principles of developing Aggression Questionnaire[9], [60]-[64], compilation of scoring guidelines, Item validation and repair items; (2) trying out the instrumentconsisting to expert validation, the instrument which consisted of 94 items became 88 items that had been repaired for further testing; (3) establishing instrument validity and reliability with activity trying out the instrument and (4) interpreting the assessment scores [65].

\section{Findings}

\section{Validity}

The concept of validity is very important in a measurement. An instrument can be said to be valid when measuring what should be measured. The development of the Aggressive Behavior Inventory (ABI) instrument is evaluated whether it is able to measure what should be measured. In this case the extent to which the instrument measures the aggressive behavior of students. Validity analysis uses Principal Component Analysis (PCA) of residuals, which measures the extent to which the diversity of $\mathrm{ABI}$ instruments measures what should be measured. PCA analysis uses 2 parameters, first the value of total raw variance in observation (minimum 20\%) and second value of total raw unexplained variance (minimum 15\%)[66]. Further information is 
presented in Table 1 below.

Table 1. Standardized Residual Variance

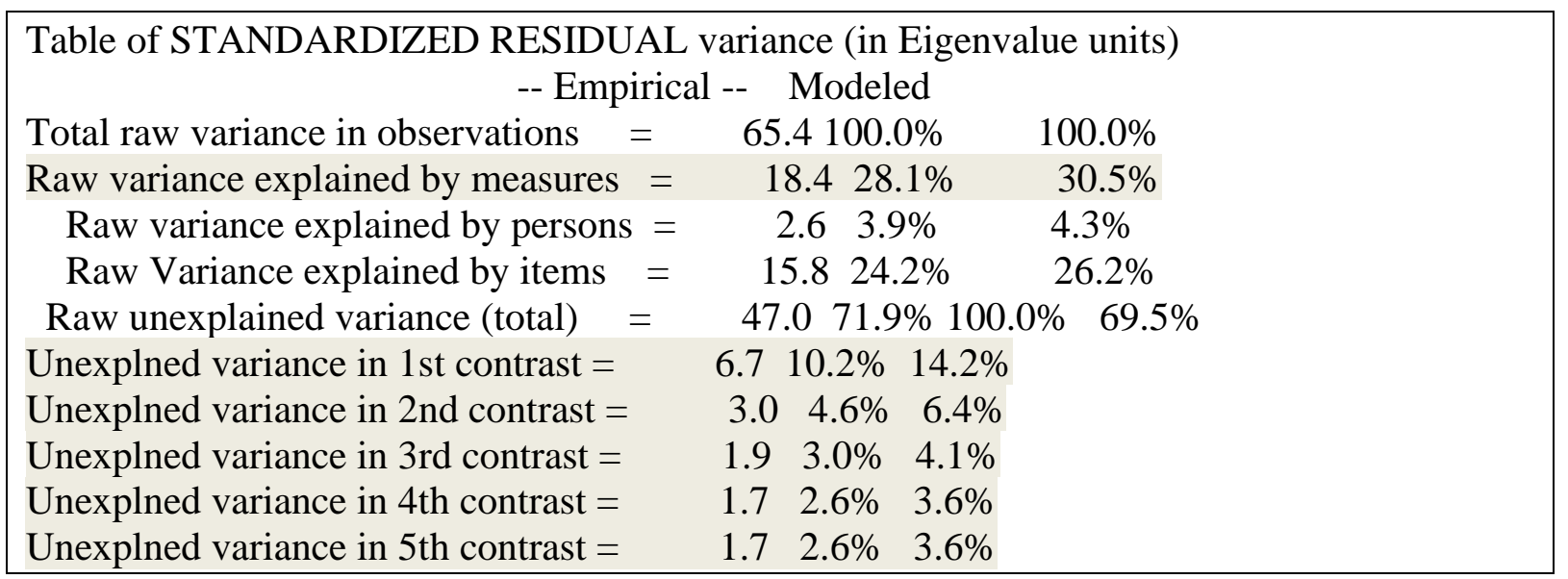

In Table 1 above, it can be seen that the total raw variance result is $28.1 \%$, not much different from the expected value of $30.5 \%$. This shows that the minimum unidimensional requirements of $20 \%$ have been met[66]. While all unexplained variance results ( 1 st to 5 th) are below $15 \%$ which shows the level of independence of items in a good instrument. Thus this condition states that the instrument unidimensionality requirements are met, further it can be stated that 47 items used in the ASBI instrument are valid.

\section{Validity of respondents}

The instrument validity of respondents uses variable maps that can show the distribution of students' abilities on the left and the level of difficulty items on the right [57]. Further it is conveyed in Figure 1 below.

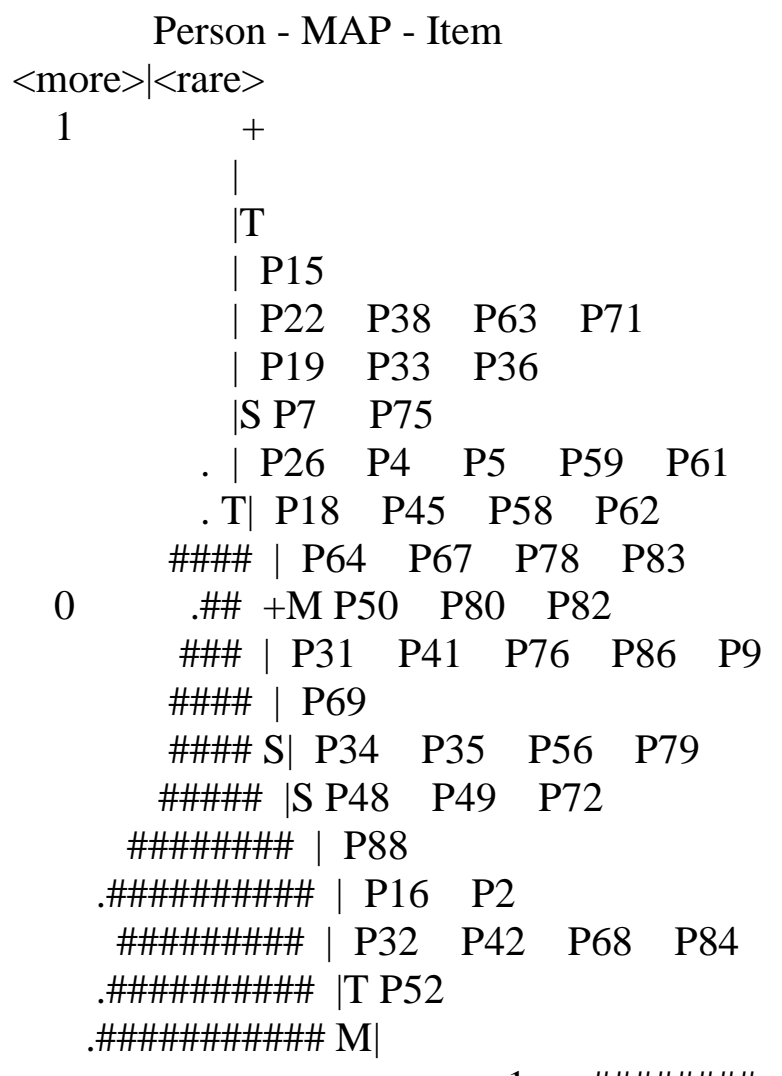




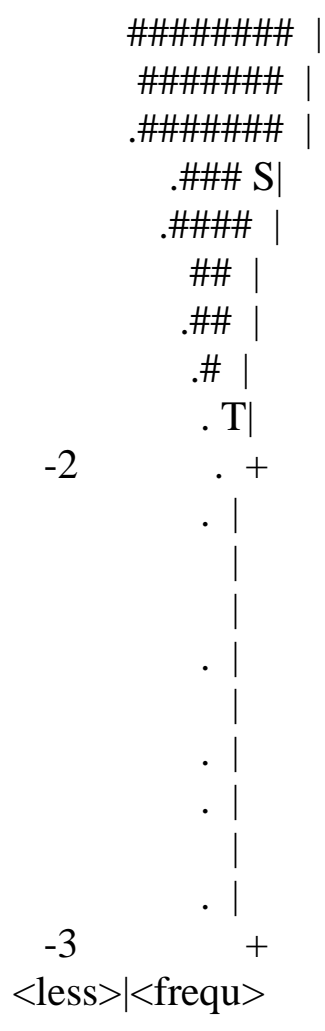

Figure 1. Variable maps (person 360 and 47 items)

Based on Figure 1, the first left wright map shows that there is one student $(295 \mathrm{~L})$ whose level of ability is higher $(+0.32)$ than other students. There are also ten students (94P, 194P, 96P, 284P, 290P, 167P, 208P, 286P, $171 \mathrm{P}$, and 349P) with a low level of ability (1.86 to -2.91 logit) which shows the ability to answer low questions P52 (-0.80 logit) is not able to answer correctly. From the results of the analysis of map variables for female students (94) it can be stated that the lowest aggressive level with the mean value is (-2.91 logit). While male students (295) can be stated that the highest aggressive level with the mean value is $(+0.32$ logit $)$.

Second, the right map explains the distribution of logit points in items. Item P15 is a problem with the highest difficulty level (+0.69 logit), which means that the probability of all students working correctly on this problem is small. can do it right, low logit value (-0.80 logit). With the statement P52 is "When talking about bad friends, I better go".
Third, comparing the distance between M-S-T (mean, 1SD and 2SD) on the above variable maps shows that the left side of the maps of the distribution of students' ability is greater than the distribution of the level of items on the right. In this context, the items show diversity, but the distribution of 360 students' ability is wider and wider. This means that the ability of 360 students is unable to reach the items with high ability.

Fourth, comparing the mean value of the person and the mean value of the item. The mean person value of 360 respondents is -0.85 , while the mean value of the item is +0.00 . This shows that the ability of the person is too low from the problem difficulty level.

\section{Item validation}

By analyzing item measures can reveal statistical fit. The parameters used are infit and outfit of mean square with an ideal range $(0.5>\mathrm{MNSQ}<1.5)$ and standardized values with an ideal range (-2.0> ZSTD <+2.0) [57], [58], [67]. Further information is presented in Table 2 below. 
Table 2.Item Misfit

\begin{abstract}
|ENTRY TOTAL TOTAL
MODEL I INFIT | OUTFIT |PT-MEASURE |EXACT MATCH|

|NUMBER SCORE COUNT MEASURE S.E. |MNSQ ZSTD|MNSQ ZSTD|CORR. EXP.| OBS\% EXP\%| Item |
\end{abstract}

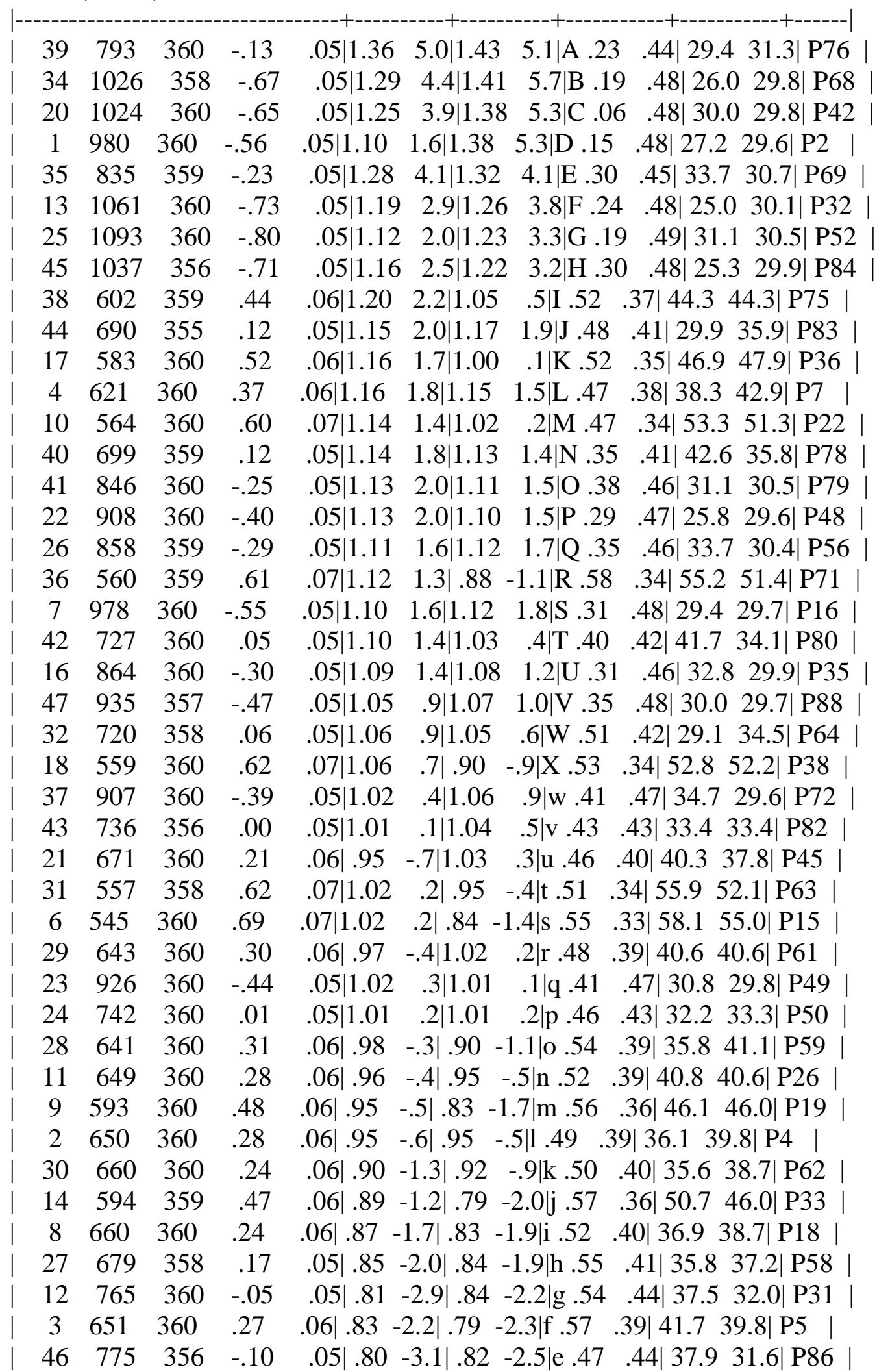




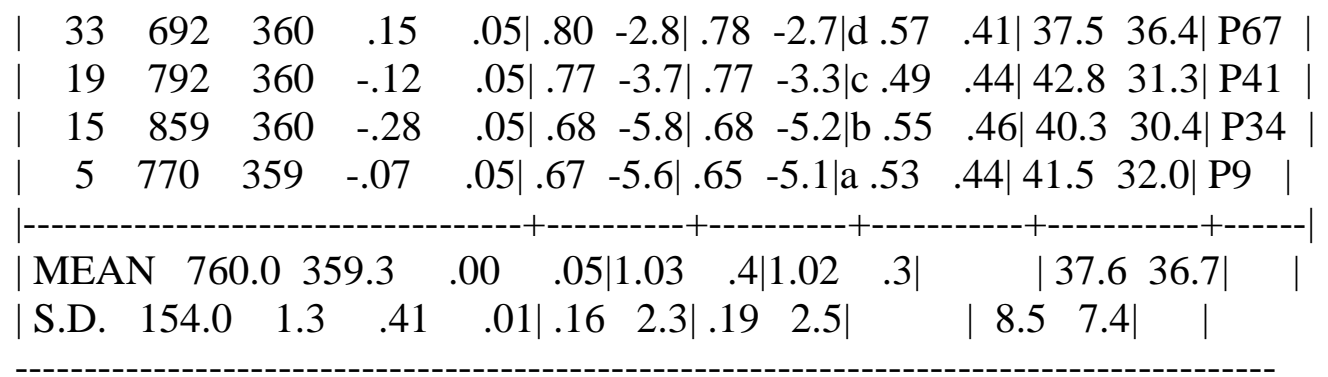

In Table 2, show the order items misfit order. There are eight misfit items namely, P76, P68, P42, P2, P69, P32, P52, P84. Judging from the standardized values (ZSTD)> 3.0 it has passed the ideal range, which is $(-2.0>$ ZSTD $<+2.0)$ so that the items need to be changed to meet the suitability statement.

\section{Reliability}

The reliability of an instrument refers to the stability of a measurement and consistency in measurement. To obtain information about the reliability of the person and the reliability of the items can be displayed in a statistical summary. The results of the statistical summary are explained further in Table 3 below.

Table 3. Summary statistics

SUMMARY OF 360 MEASURED Person

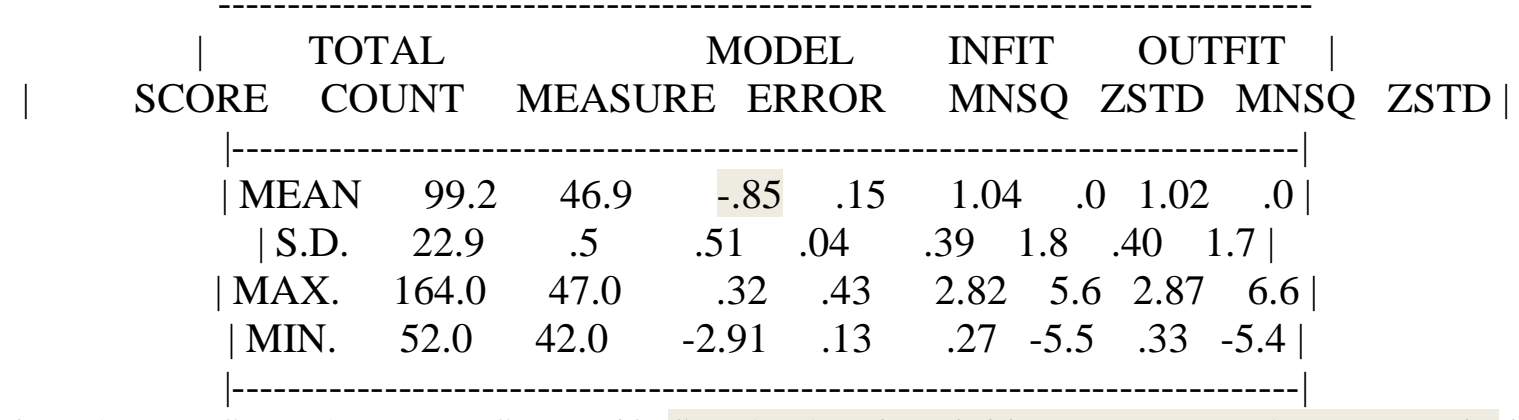

| REAL RMSE $\quad .17$ TRUE SD $\quad .48$ SEPARATION 2.80 Person RELIABILITY .89| |MODEL RMSE .16 TRUE SD $\quad .48$ SEPARATION 3.07 Person RELIABILITY .90| | S.E. OF Person MEAN = .03

Person RAW SCORE-TO-MEASURE CORRELATION $=.97$ CRONBACH ALPHA (KR-20) Person RAW SCORE "TEST" RELIABILITY = .91 SUMMARY OF 47 MEASURED Item

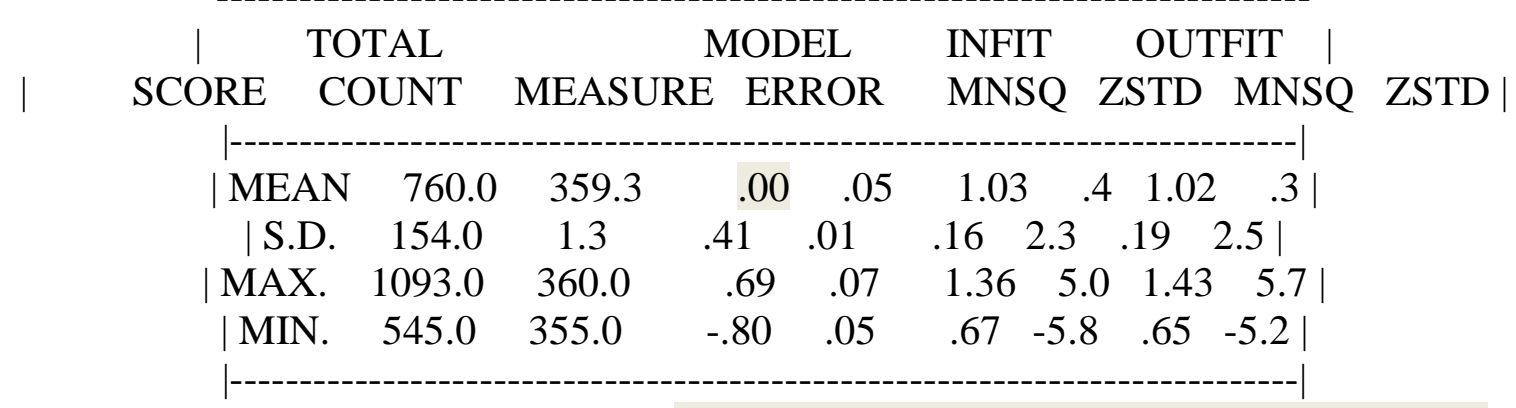

| REAL RMSE $\quad .06$ TRUE SD .41 SEPARATION 7.25 Item RELIABILITY .98 | |MODEL RMSE .05 TRUE SD .41 SEPARATION 7.52 Item RELIABILITY $.98 \mid$ | S.E. OF Item MEAN $=.06$ 
In Table 3, it can be seen that the personal reliability score is 0.89 and the item reliability score is 0.98 . This shows that the quality of the answers given by the person is good and the quality of the items used in the measurement is special. While the Cronbach alpha value (KR20 ) is 0.91 , which indicates that reliability is good in measuring interactions between people and items.

Furthermore, person and item grouping can be known from the separation value by using the strata person formula $\mathrm{H}$, so the value of $\mathrm{H}=[(4$ * separation) +1 ] / 3[57]. The value of separation person 2.80 , then $\mathrm{H}=[(4 * 2.80)+$ 1] $/ 3, \mathrm{H}=4.06$ (rounded to 4 ). This shows 4 groups of respondents (high, medium, low, and very low ability). Judging from the value of separation items 7.25 , then $\mathrm{H}=10$ it can be concluded that the items are able to reach individual abilities high, high, and very high.

\section{Differential item functioning (DIF)}

Measuring instruments and items can be biased because of differences in which certain items will favor one particular type (eg gender, family background, etc.). In Table 4 the following DIF analysis results are displayed, which can be determined by the probability value below (0.05) showing items that are biased [57].

Table 4.Differential item functioning (DIF)

\begin{tabular}{|c|c|c|c|c|c|c|c|}
\hline $\mid$ Per & & SU & IMARY D & & BETWEEN-CLA & & em \\
\hline CLASSES & & & ARE D. & PROB. & MEAN-SQUARE & $=\mathrm{ZSTD}$ & \\
\hline & & 4 & 4.9800 & 3.1723 & $.4298-.6293$ & $1 \mathrm{P} 2$ & \\
\hline & & 4 & 4.9429 & 3.1751 & $.4844-.5164$ & $2 \mathrm{P} 4$ & \\
\hline & & 4 & 13.0876 & 3.0044 & $1.0098 \quad .2841$ & 3 P5 & \\
\hline & & 4 & 15.7278 & 3.0013 & $\begin{array}{ll}1.6060 \quad 9007\end{array}$ & $4 \mathrm{P} 7$ & \\
\hline & & 4 & .2814 & 3.9637 & $.0256-2.3199$ & $5 \mathrm{P} 9$ & \\
\hline & & 4 & 12.5155 & 3.0057 & $\begin{array}{ll}1.1029 & .3941\end{array}$ & $6 \mathrm{P} 15$ & \\
\hline & & 4 & 12.3660 & 3.0062 & $.9996 \quad .2716$ & 7 P16 & \\
\hline & & 4 & 8.1250 & 3.0431 & $.7075-.1280$ & $8 \mathrm{P} 18$ & \\
\hline & & 4 & 22.8104 & 3.0000 & 2.38441 .5066 & 9 P19 & \\
\hline & & 4 & 13.8491 & 3.0031 & $1.3129 \quad .6212$ & $10 \mathrm{P} 22$ & \\
\hline & & 4 & 9.8949 & 3.0193 & .9713 .2367 & $11 \mathrm{P} 26$ & \\
\hline & & 4 & 6.9176 & 3.0740 & $.5526-.3870$ & $12 \mathrm{P} 31$ & \\
\hline & & 4 & 10.0380 & 3.0181 & $.9140 \quad .1637$ & 13 P32 & \\
\hline & & 4 & 15.8014 & 3.0012 & $1.6214 \quad .9145$ & 14 P33 & \\
\hline & & 4 & 1.3965 & 3.7058 & $.1283-1.5488$ & 15 P34 & \\
\hline & & 4 & 11.8097 & 3.0080 & $1.1142 \quad .4070$ & $16 \mathrm{P} 35$ & \\
\hline & & 4 & 27.5855 & 3.0000 & 2.94421 .8640 & 17 P36 & \\
\hline & & 4 & 17.0439 & 3.0007 & 1.77561 .0471 & 18 P38 & \\
\hline & & 4 & 4.2247 & 3.2371 & $.3898-.7182$ & 19 P41 & \\
\hline & & 4 & 5.0609 & 3.1665 & $.4406-.6062$ & $20 \mathrm{P} 42$ & \\
\hline & & 4 & 4.2005 & 3.2395 & $.3668-.7720$ & $21 \mathrm{P} 45$ & \\
\hline & & 4 & 9.4859 & 3.0233 & $\begin{array}{ll}.8178 & .0339\end{array}$ & $22 \mathrm{P} 48$ & \\
\hline & & 4 & 4.2843 & 3.2313 & $.3972-.7013$ & $23 \mathrm{P} 49$ & \\
\hline & & 4 & 6.1895 & 3.1021 & $.5746-.3475$ & 24 P50 & \\
\hline & & 4 & 14.6597 & 3.0021 & $1.3444 \quad .6531$ & 25 P52 & \\
\hline
\end{tabular}




\begin{tabular}{|c|c|c|c|c|}
\hline 4 & 3.1825 & 3.3631 & $.2781-1.0039$ & 26 P56 \\
\hline 4 & 4.0550 & 3.2544 & $.2937-.9597$ & 27 P58 \\
\hline 4 & 14.6912 & 3.0021 & $1.4796 \quad .7847$ & 28 P59 \\
\hline 4 & 2.5790 & 3.4600 & $.2470-1.0966$ & 29 P61 \\
\hline 4 & 6.6307 & 3.0841 & $.6229-.2641$ & 30 P62 \\
\hline 4 & 9.1714 & 3.0269 & $.8969 \quad .1413$ & 31 P63 \\
\hline 4 & 1.0077 & 3.7991 & $.0964-1.7174$ & 32 P64 \\
\hline 4 & 1.6560 & 3.6460 & $.1575-1.4177$ & 33 P67 \\
\hline 4 & 25.9050 & 3.0000 & $2.3697 \quad 1.4964$ & 34 P68 \\
\hline 4 & 24.1424 & 3.0000 & $2.2381 \quad 1.4041$ & 35 P69 \\
\hline 4 & 18.8846 & 3.0003 & 1.86441 .1201 & 36 P71 \\
\hline 4 & 5.7725 & 3.1224 & $.4999-.4861$ & 37 P72 \\
\hline 4 & 6.9495 & 3.0730 & $.6415-.2332$ & 38 P75 \\
\hline 4 & 12.6958 & 3.0053 & $\begin{array}{ll}1.2461 \quad .5518\end{array}$ & $39 \mathrm{P} 76$ \\
\hline 4 & 4.5139 & 3.2100 & $.3647-.7769$ & 40 P78 \\
\hline 4 & 12.9061 & 3.0048 & $\begin{array}{ll}1.2198 & .5237\end{array}$ & 41 P79 \\
\hline 4 & 14.2047 & 3.0026 & $1.3932 \quad .7015$ & 42 P80 \\
\hline 4 & 2.5877 & 3.4585 & $.1980-1.2605$ & 43 P82 \\
\hline 4 & 8.5350 & 3.0358 & $.6761-.1773$ & $44 \mathrm{P} 83$ \\
\hline 4 & 4.6506 & 3.1982 & $.3278-.8686$ & $45 \mathrm{P} 84$ \\
\hline 4 & 3.2729 & 3.3502 & $.2442-1.1054$ & 46 P86 \\
\hline 4 & 7.8053 & 3.0498 & $.6571-.2077$ & 47 P88 \\
\hline
\end{tabular}

In Table 4 above, it appears that 22 items that are not biased are P2, P4, P9, P31, P34, P41, P42, P45, P49, P50, P56, P58, P61, P62, P64, P67, P72, P75, P78, P82, P84, and P86. The number of items that are biased shows that differences in students' assessment of aggressive behavior are influenced by a variety of things, namely gender, parental educational background, culture, and economic level of parents.

\section{Rating Scale Validation}

The validity of the rating scale is very important in the measurement, because the rating scale is used to test the verification of the rating of the choice used. In the $\mathrm{ABI}$ instrument, it uses answer choices in the form of likert rating for each item. Respondents gave answers in accordance with their situation on each item given. Respondents' answers are seen based on whether the choice of answers given by respondents moves to the leftmost column 1 with the choice Always or the rightmost column 5 with the option Never. This choice contrasts the level of students' aggressive behavior in each item. More is presented in Figure 2 below.

In figure 2 above shows the number $1=$ always, $2=$ often, $3=$ rarely, $4=$ sometimes, and $5=$ never. Further to know the size of the ranking validity called Andrich Threshold, which shows the transition that occurs in decision making by respondents from one rank to the next [66]. Andrich Threshold value that moves from option 1 (none), then to option 2 (0.50 logit), choice 3 (-0.30 logit), choice 4 ($0.19)$, and choice 5 (+1.00 logit). It can be seen that the value of Andrich Threshold moves from none then negative and leads to positive sequentially indicating that the five choices given are valid for the respondent. 


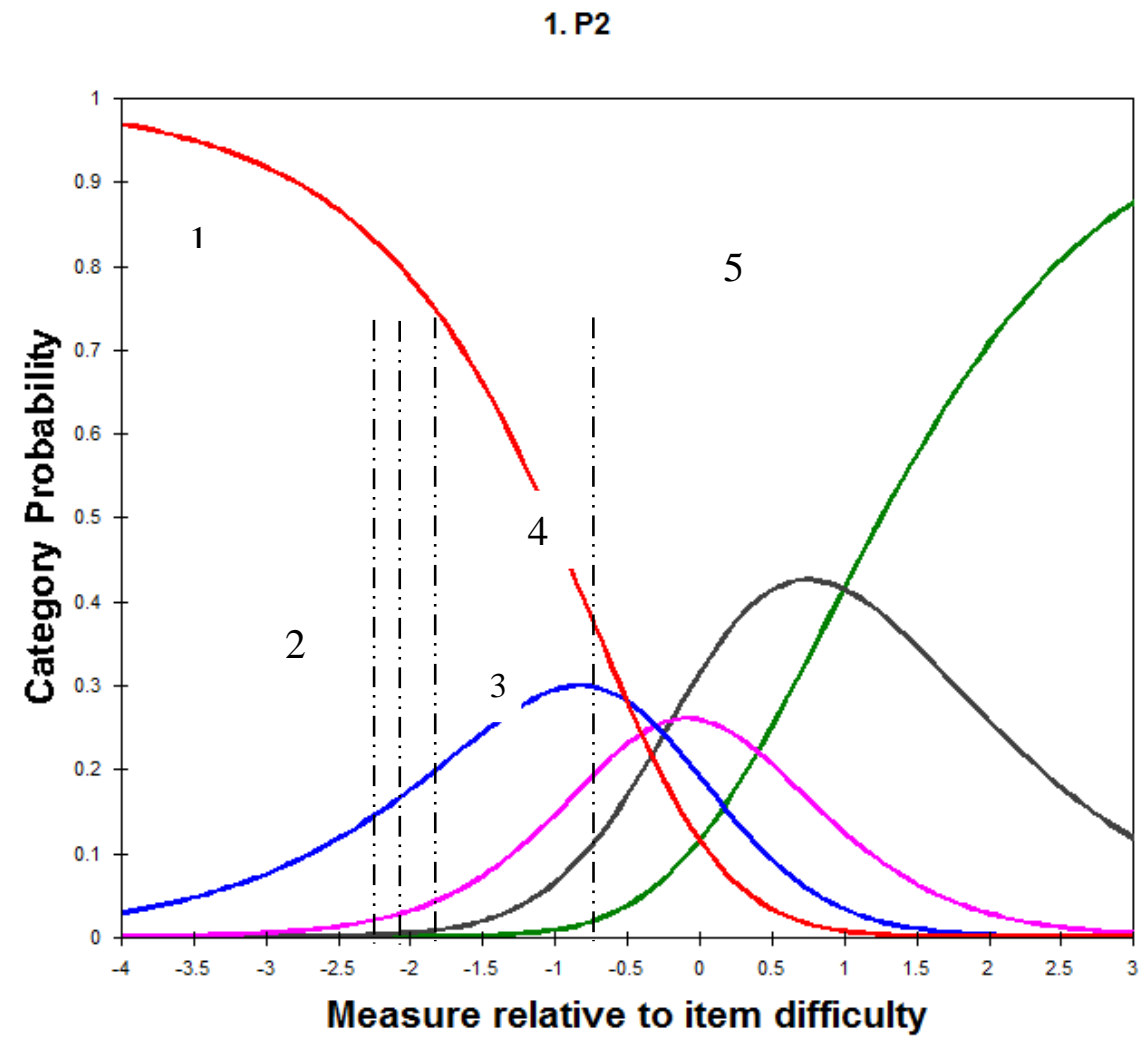

Figure 2.Response functions for a Likert-style item with 5 categories (item 47) and disordered threshold estimates

\section{Discussion}

Based on research results. Measurement of aggressive behavior of junior high school students, classified valid and reliable helps further researchers to uncover aggressive behavior. Rasch analysis conducted can see the suitability of person and item, and can conduct analysis up to the item and item level level, analysis at the instrument level can also be done

Empirical research found many researchers who created instruments of aggressive behavior in the fields of health, sports, social and education. Development of the Agregession Questionnaire (AQ) given to high school students in Egypt with a sample of 510 free bias between men and women [61]. Limitations in the Aggession Questionnaire (AQ) is the small number of items (29 items). So the researchers developed the Aggressive Behavior Inventory (ABI) by making physical, verbal, angry, and hostile forms of aggressive behavior into 12 indicators with a total of 47 items so that they were more representative of aggressive behavior that often occurs in junior high schools in Indonesia.

Furthermore, when compared to other instruments such as SDAS (social dysfunction and aggression scale) instruments, it is not only to measure aggressive behavior but can also predict aggressive events as recorded by SOAS-R (staff observation revised scale aggression). Therefore, it is very useful to apply both instruments, SDAS and SOAS-R, as well as in recording aggressive behavior [68]. The limitations of both the SDAS and SOAS-R instruments have been designed for forensic psychiatric patients. However, to measure the aggressive behavior of junior high school students, an appropriate instrument is needed, using the $\mathrm{ABI}$ instrument can measure aggressive behavior in junior high schools.

Comparison between two measuring instruments conducted in high school namely Eleven items of a certain instrument (CORT 2004 Inventory) and Freiburg Personality Inventory (FPI). Comparison of two instruments to reduce psychosomatic in aggressive students by increasing feelings of 
pleasure [69]. Its limitations are as descriptive needs assessment and not to test causal hypotheses. So it is difficult to measure a lot of students to see aggressive behavior using the CORT instrument because it spends time describing many students. The need for an ASBI instrument to measure a large number of students. verbal forms, anger emotions, and hostility displayed physically by utilizing the Rasch model program in analyzing.

Furthermore, aggression in sports, the development of a scale to measure aggressiveness and anger in competition. The Competitive Aggressiveness and Anger Scale (CAAS) looks at how aggressiveness in sports, individuals who behave aggressively due to regulations that allow individuals to engage in aggressive behavior but anger that causes athletes ignores the rules [70]. The limitation of the scale is only the understanding of aggression in sports and incomplete measurement of anger. This instrument does not precisely measure aggressive behavior in junior high school because this CAAS instrument is designed to look at aggressive behavior in sports. So the need for the ABI instrument by looking at aggressive physical behavior, anger and animosity in junior high school.

\section{Conclusion}

Aggressive behavior is one of the behaviors of students that requires attention from various parties. Schools as a place of formal education have a responsibility in dealing with aggressive behavior of students. The conclusion of this study is that the ABI instrument is valid and reliable for measuring the aggressive behavior of junior high school students with a total of 47 items. The advantages of the ABI instrument are being able to measure in the form of verbal, emotional anger, and physical displayed hostility that is related to behavior that is often done in junior high school.

This instrument is an alternative that can be used by field study teachers and counselors to reveal the level of aggressive behavior of junior high school students. appropriate for aggressive children. Just as subject teachers use instruments that aim to improve learning strategies. All parties in the school, namely subject teachers, counselors and administrators have responsibilities and have important roles. One who has a role important is the guidance and counseling teacher or counselor. One of the functions of guidance and counseling is the prevention function, namely efforts to intervene in the need for assistance.

The results of the instrument can also assist the school in designing programs to prevent aggressive behavior of students by completing the necessary facilities and infrastructure

\section{Acknowledgment}

The researcher would like to express his thanks to the Ministry of Research and Technology and Higher Education, UniversitasNegeri Padang, Students and Teachers at 8 Middle Schools in West Sumatra who have helped facilitate this research

\section{References}

[1] K. Z. Saputro, "Memahami ciri dan tugas perkembangan masa remaja," Apl. J. Apl. Ilmu-ilmu Agama, vol. 17, no. 1, pp. 25-32, 2018.

[2] Z. Sharif and N. Mohamad Roslan, "Faktorfaktor yang mempengaruhi remaja terlibat dalam masalah sosial di Sekolah Tunas Bakti, Sungai Lereh, Melaka," J. Educ. Psychol. Couns., vol. 1, no. 7, pp. 115-140, 2011.

[3] E. Estévez, T. I. Jiménez, and D. Moreno, "Aggressive behavior in adolescence as a predictor of personal, family, and school adjustment problems.," Psicothema, vol. 30, no. $1,2018$.

[4] S. Lin, C. Yu, J. Chen, W. Zhang, L. Cao, and L. Liu, "Predicting adolescent aggressive behavior from community violence exposure, deviant peer affiliation and school engagement: A one-year longitudinal study," Child. Youth Serv. Rev., vol. 111, p. 104840, 2020.

[5] F. Tentama, "Perilaku anak agresif: 
Asesmen dan intervensinya," J. Kesehat. Masy. (Journal Public Heal., vol. 6, no. 2, 2013.

[6] Y. Restu, Y. Yusri, and Z. Ardi, "Studi tentang perilaku agresif siswa di sekolah," Konselor, vol. 2, no. 1, 2013.

[7] Atkinson. L.R, Pengantar Psikologi jilid 2. Jakarta: Interaksara, 2010.

[8] D. G. Myers, Psikolog Sosial Edisi 10. Terjemahan oleh Aliya Tusyani, dkk. Jakarta: Salemba Humanika, 2012.

[9] A. H. Buss and M. Perry, "Personality Processes and Individual The Aggression Questionnaire," J. Pers. Soc. Psychol., vol. 63, no. 3, pp. 452-459, 1992.

[10] L. Berkowitz, Agresi I, Sebab dan Akibatnya. Terjemahan Hartati Woro Susiatni. Jakarta: Pustaka Binaman Pressindo, 2005.

[11] S. E. Taylor, L. A. Peplau, and D. O. Sears, Psikologi Sosial Edisi Kedua Belas. Jakarta: Kencana Prenada Media Group, 2009.

[12] E. B. Hurlock, Psikologi Perkembangan: Suatu pendekatan sepanjang rentang kehidupan. Jakarta: Erlangga, 2011.

[13] S. Su'ud, "Remaja dan Perilaku Menyimpang Studi Kasus pada Masyarakat Boepinang, Bombana. Jurnal Psikologi (Online)," J. Psychol., vol. 1, no. 34, 2011.

[14] J. Siagian, “Tinjauan tentang Perilaku Menyimpang Remaja di Kelurahan Titi Rantai Kecamatan Medan Baru Kota Medan (online)," J. Psikol., vol. 1, no. 1, 2011.

[15] E. Koeswara, Agresif Manusia. Bandung: Erasco, 1998.

[16] T. F. Denson, M. Spanovic, F. E. Aviles, V. E. Pollock, M. Earleywine, and N. Miller, "The Effects of Acute Alcohol Intoxication and Self-Focused Rumination on Triggered Displaced Aggression," J. Aggress. Maltreat. Trauma, vol. 20, no. 2, pp. 128-
147, 2011, doi: 10.1080/10926771.2011.546750.

[17] P. S. Keller, S. Blincoe, L. R. Gilbert, and E. A. Haak, "Journal of Aggression, Maltreatment \& Sleep Deprivation and Dating Aggression Perpetration in Female College Students : The Moderating Roles of Trait Aggression, Victimization by Partner, and Alcohol Use," no. March 2015, pp. 3741, 2014, doi: 10.1080/10926771.2014.896838.

[18] M. T. Tull, M. Jakupcak, A. Paulson, and K. I. M. L. Gratz, "The role of emotional inexpressivity and experiential avoidance in the relationship between posttraumatic stress disorder symptom severity and aggressive behavior among men exposed to interpersonal violence," in Anxiety Stress and Coping, 2007, vol. 20, no. December, pp. 337-352, doi: $10.1080 / 10615800701379249$.

[19] S. Willis, Remaja dan Masalahnya. Bandung: Alfabeta, 2010.

[20] R. B. Casselman and A. Rosenbaum, "Journal of Aggression, Maltreatment \& Fathers, Sons, and Aggression:A Path Model Adverse Childhood Experiences , Gender Roles , Developmental Issues And The Child Welfare System," no. February 2015, pp. 37-41, 2014, doi: $10.1080 / 10926771.2014 .904464$.

[21] B. S. Arifin, Psikologi Sosial. Bandung: Pustaka Setia, 2015.

[22] S. E. Goldstein, "Adolescents ' Disclosure and Secrecy About Peer Behavior: Links with Cyber Aggression , Relational Aggression , and Overt Aggression," $J$. Child Fam. Stud., vol. 25, no. 5, pp. 14301440, 2016, doi: 10.1007/s10826-015-03402.

[23] J. P. Wyckoff, "Aggression and emotion: Anger, not general negative affect, predicts desire to aggress," PAID, vol. 101, pp. 220 226, 2016, doi: 10.1016/j.paid.2016.06.001. 
[24] A. Casey, T. T. Suzannah, and K. C. Christopher, "Anger and Aggression in PTSD," Curr. Opin. Psychol., pp. 1-17, 2016, doi: 10.1016/j.copsyc.2016.11.008.

[25] A. M. Cohn, M. Jakupcak, L. A. Seibert, T. B. Hildebrandt, and A. Zeichner, "The Role of Emotion Dysregulation in the Association Between Men 's Restrictive Emotionality and Use of Physical Aggression," Psychol. Men Masc., vol. 11, no. 1, pp. 53-64, 2010, doi: $10.1037 / \mathrm{a} 0018090$.

[26] F. Roll, J., Koglin, U., \& Petermann, "Emotion Regulation and Childhood Aggression :" Child Psychiatry Hum. Dev., vol. 43, pp. 909-923, 2012, doi: 10.1007/s 10578-012-0303-4.

[27] A. Debono et al., "Understanding maladaptive responses to rejection: Aggression with an audience Understanding maladaptive responses to rejection: Aggression," vol. 4545, no. April, 2016, doi: 10.1080/00224545.2016.1165168.

[28] M. B. Harris, “Aggressive experiences and aggressiveness: Relationship to ethnicity, gender, and age," J. Appl. Soc. Psychol., vol. 26 , no. 10, pp. 843-870, 1996, doi: 10.1111/j.1559-1816.1996.tb01114.x.

[29] J. H. Park, "Aggressor/victim subtypes and teacher factors in first grade as risk factors for later mental health symptoms and school functioning," Asia Pacific Educ. Rev., vol. 7, no. 1, pp. 108-119, 2006, doi: 10.1007/BF03036789.

[30] C. P. Barlett, R. J. Harris, and C. Bruey, "The effect of the amount of blood in a violent video game on aggression, hostility, and arousal," J. Exp. Soc. Psychol., vol. 44, no. 3, pp. 539-546, 2008, doi: 10.1016/j.jesp.2007.10.003.

[31] K. M. Welker, R. E. Norman, S. Goetz, B. J. P. Moreau, S. Kitayama, and J. M. Carr, "Preliminary evidence that testosterone's association with aggression depends on selfconstrual," Horm. Behav., pp. 1-62,
2016, doi: 10.1016/j.yhbeh.2016.10.014.

[32] H. Cho, S. Lee, J. Choi, S. Choi, and D. Kim, "An exploratory study on association between Internet game contents and aggression in Korean adolescents," Comput. Human Behav., 2016, doi: 10.1016/j.chb.2016.12.077.

[33] B. Krahe, Perilaku Agresi. Yogyakarta: Pustaka Pelajar, 2005.

[34] B. P. Statistik, Statistik Kriminal 2016. Jakarta: Badan Pusat Statistik, 2016.

[35] A. Afdal, A. Alizamar, I. Ifdil, E. Erlamsyah, and T. Taufik, "Guidance And Counseling Services For Women Victims Of Domestic Violence," Adv. Soc. Sci. Educ. Humanit. Res., vol. 118, no. 23, pp. 935-939, 2017.

[36] Siswanto, Karimullah, R. Prasetyawati, and Nurhayati, "Environmental cultured education and its implication on the student's competencies in an adiwiyata school," Cakrawala Pendidik., vol. 38, no. 3, pp. 552-564, 2019, doi: 10.21831/cp.v38i3.23154.

[37] E. Supriyadi, Zamtinah, S. Soenarto, and Y. I. Hatmojo, "A character-based assessment model for vocational high schools," Cakrawala Pendidik., vol. 38, no. 2, pp. 269-280, 2019, doi: 10.21831/cp.v38i2.24099.

[38] A. Buss, The psychology of aggression. New York: John Wiley \& Sons, Inc, 1961.

[39] J. Little, T., S. Ones, C. Henrich, and P. Hawley, "Disentangling the "whys' from the 'whats' of aggressive behaviour," Int. J. Behav. Dev., vol. 27, pp. 122-133, 2003.

[40] C. Anderson and B. Bushman, "Human aggression," Annu. Rev. Psychol., vol. 53, pp. 27-51, 2002.

[41] G. Von Collani and R. Werner, "Self-related and motivational constructs as determinants of aggression . An analysis and validation of 
a German version of the Buss - Perry Aggression Questionnaire," vol. 38, pp. 1631-1643, 2005, doi: 10.1016/j.paid.2004.09.027.

[42] A. Cyba, D. Álvarez-garcía, A. Barreirocollazo, J. Carlos, and A. Dobarro, "The European Journal of Psychology Applied to Legal Context," vol. 8, pp. 69-77, 2016, doi: 10.1016/j.ejpal.2016.02.003.

[43] Pechorro, R. Barroso, C. Poiares, J. P. Oliveira, and O. Torrealday, "Validation of the Buss-Perry aggression questionnaireshort form among Portuguese juvenile delinquents," Int. J. Law Psychiatry, vol. 44, no. 2016, pp. 75-80, 2016.

[44] M. Morren and C. Meesters, "Validation of the Dutch version of the Aggression Questionnaire in adolescent male offenders," Aggress. Behav., vol. 28, pp. 87-96, 2002.

[45] A. Vigil-Colet, U. Lorenzo-Seva, M. Codorniu-Raga, and F. Morales, "Factor structure of the Buss-Perry Aggression Questionnaire in different samples and languages," Aggress. Behav., vol. 31, pp. 601-608, 2005.

[46] J. Maxwell, "Development and preliminary validation of a Chinese version of the BussPerry Aggression Questionnaire in a population of Hong Kong Chinese," J. Pers. Assess., vol. 88, no. 3, pp. 284-294, 2007.

[47] V. Nahama, M. P. Ayoub, R. Borie, and F. Petit, "Problemes d'adaptation sociale chez des jeunes de 9 a 12 ans presentant des troubles des apprentissages [Social adjustment problems of youngsters with learning difficulties]," Approch. Neuropsychol. des Apprentissages chez l'Enfant, vol. 15, pp. 9-13, 2003.

[48] A. Fossati, C. Maffei, E. Acquarini, and A. Di Ceglie, "Multigroup confirmatory component and factor analyses of the Italian version of the Aggression Questionnaire," Eur. J. Psychol. Assess., vol. 19, pp. 54-65,
2003.

[49] H. H. M. Jani and M. R. M. Hussain, "Reclaiming the Loss of the Minangkabau Cultural Landscape in Negeri Sembilan," Procedia-Social Behav. Sci., vol. 153, no. 2014, pp. 317-329, 2014.

[50] M. Radjab, Sistem Kekerabatan di Minangkabau. Center for Minangkabau Studies Press, 1969.

[51] S. Hanani, "Tradisi Ulama Transformatif Minangkabau dalam Membangun Pendidikan Karakteristik Berbasis Responsif Teologis dan Kontribusinya Terhadap Penguatan Moralitas," Sos. Budaya, vol. 12, no. 2, pp. 191-202, 2016.

[52] L. Hadijah, "Local Wisdom in Minangkabau Cultural Tradition of Randai," KnE Soc. Sci., pp. 399-411, 2019.

[53] A. Jamrah, "Character Education Development Model Based Values" Tau Jo Nan Ampek" At High School Level In The City Batusangkar," Proceeding IAIN Batusangkar, vol. 1, no. 1, pp. 153-164, 2017.

[54] Afdal, Alizamar, Ifdil, and Zikra, Pengembangan Model Konseling Keluarga Eksperensial untuk Penyelesaian Kasus Kekerasan Dalam Rumah Tangga (Tahun ke dua). Laporan Penelitian Unggulan Dasar Perguruan Tinggi. Padang: UNP, 2017.

[55] M. Farozin, "Counselor professional identity of counselor profession education," Cakrawala Pendidik., vol. 38, no. 1, pp. 104-119, 2019, doi: 10.21831/cp.v38i1.22515.

[56] Trianto, Model Pembelajaran Terpadu. Jakarta: Bumi Aksara, 2012.

[57] B. Sumintono and W. Widhiarso, Aplikasi Pemodelan Rasch pada Assessment Pendidikan. Bandung: Trim Komunikata, 2015.

[58] T. G. Bond and C. M. Fox, Applying the 
Rasch Model, Fundamentals Measurement in the Human Science (3rd edition). New York: Routledge, 2015.

[59] S. Alagumalai, D. D. Curtis, and N. Hungi, a Pplied Rasch Measurement: a Book of Exemplars Education in the Asia-Pacific Region: Issues, Concerns and Prospects. Netherlands: Springer, 2005.

[60] C. Reyna, M. G. L. Ivacevich, A. Sanchez, and S. Brussino, "The Buss-Perry Aggression Questionnaire: Construct Validity and Gender Invariance Among Argentinean Adolescents," Int. J. Psychol. Res., vol. 4, no. 2, pp. 30-37, 2011.

[61] S. M. Abd-El-Fattah, "Is the aggression Questionnaire bias free? A Rasch analysis," Int. Educ. J., vol. 8, no. 2, pp. 237-248, 2007.

[62] M. C. Singh and R. K. N. Singh, "Aggression Between Boys and Girls Inter School U-17 Footballers of Manipur," Int. J. Res., vol. 4, no. 1, pp. 119-124, 2016.

[63] H. Værøy, “Aggression questionnaire scores in extremely violent male prisoners, male bodybuilders, and healthy non-violent men," Open J. Psychiatry, vol. 3, pp. 293300, 2013, doi: 10.4236/ojpsych.2013.33029.

[64] F. B. Bryant and B. D. Smith, "Refining the Architecture of Aggression: A Measurement Model for the Buss-Perry Aggression Questionnaire," J. Res. Pers., vol. 35, no. 2, pp. 138-167, 2001, doi: 10.1006/jrpe.2000.2302.

[65] L. . Oriondo and E. . Dallo-Antonio, Evaluation Educational Outcomes (Test, Measurement, and Evaluation), (5th ed.). Queson City: Rex Printing Compagny, inc, 1998.

[66] J. M. Linacre, A User's Guide to WINSTEPS Ministeps Rasch-Model Computer Programs. 2011.
[67] W. J. Boone, J. R. Stever, and M. S. Yale, Rasch Analysis in the Human Science. Dordrech: Springer Publishing Company, LLC, 2014.

[68] M. H. B. M. Kobes, H. H. L. I. Nijman, and E. B. H. Bulten, "Assessing Aggressive Behavior in Forensic Psychiatric Patients: Validity and Clinical Utility of Combining Two Instruments," Arch. Psychiatr. Nurs., vol. 26, no. 6, pp. 487-494, 2012, doi: 10.1016/j.apnu.2012.04.004.

[69] A. Carmen, C. Caraion-buzdea, and P. Luciana, "Aggressiveness within the high school students sector: Comparison between two measurement instruments," vol. 2, no. 2, pp. 4781-4786, 2010, doi: 10.1016/j.sbspro.2010.03.770.

[1] [70] J. H. Kerr, "A critique of the development of the Competitive Aggressiveness and Anger Scale," Psychol. Sport Exerc., vol. 9, pp. 721-728, 2008, doi: 10.1016/j.psychsport.2008.01.001. 